\title{
Fly Ash from Thermal Conversion of Sludge as a Cement Substitute in Concrete Manufacturing
}

\author{
Gabriela Rutkowska ${ }^{1}$, Marek Chalecki ${ }^{1, *}$ and Mariusz Żółtowski ${ }^{2}$ \\ 1 Institute of Civil Engineering, Warsaw University of Life Sciences (SGGW), 02-776 Warszawa, Poland; \\ gabriela_rutkowska@sggw.edu.pl \\ 2 Water Center of Warsaw University of Life Sciences (SGGW), 02-776 Warszawa, Poland; \\ mariusz_zoltowski@sggw.edu.pl \\ * Correspondence: marek_chalecki@sggw.edu.pl; Tel.: +48-22-5935125
}

check for updates

Citation: Rutkowska, G.; Chalecki, M.; Żółtowski, M. Fly Ash from Thermal Conversion of Sludge as a Cement Substitute in Concrete Manufacturing. Sustainability 2021, 13, 4182. https://doi.org/10.3390/ su13084182

Academic Editors: Marzena Smol, Maria Włodarczyk-Makuła, Joanna Duda and Ludwig Hermann

Received: 12 March 2021

Accepted: 6 April 2021

Published: 9 April 2021

Publisher's Note: MDPI stays neutral with regard to jurisdictional claims in published maps and institutional affiliations.

Copyright: (c) 2021 by the authors. Licensee MDPI, Basel, Switzerland. This article is an open access article distributed under the terms and conditions of the Creative Commons Attribution (CC BY) license (https:/ / creativecommons.org/licenses/by/ $4.0 /)$.

\begin{abstract}
Striving for reduction of production costs and constraints on natural resources cause the use of waste materials as substitutes of traditional raw materials to become increasingly important. Dynamic development of sewerage systems and sewage treatment plants observed over the recent years leads to increase of mass of the produced sewage sludge. According to the Waste Law, the municipal sewage sludge can be used if it is properly stabilized, e.g., through thermal processing. This process results in significant quantities of fly ash which must be properly utilized. The paper presents results of investigations of influence of partial replacement of cement by the fly ash from sewage sludge on concrete parameters. It was designed as a C20/25 class concrete mix, based on the Portland cement CEM I 42.5R with various ash content. Physical and chemical properties of the ash as well as frost resistance and the compressive strength of the concrete after 28, 56 and 365 days of curing were investigated. The obtained results of investigations confirm the possibility of application of fly ash wastes as a cement substitute in the concrete manufacturing. If a predefined quantity of cement is replaced by the fly ash, then one can obtain cement composite with good strength parameters.
\end{abstract}

Keywords: concrete; cement; sewage sludge fly ash; properties

\section{Introduction}

Cement-a mineral hydraulic binder, built the modern world; now it turns out that it also destroys it. At the moment, it is irreplaceable; it remains a key material for the construction of the world economy. According to the data of the International Statistics Yearbook [1], the worldwide production of cement in 2000 amounted to over 1.67 billion tons and in 2013-4.07 billion tons. Currently, it is consumed at ca. 4.5 billion tons per year. The problem is that the production of 1 ton of cement, depending on the technology, causes emission of 0.5 to 1 ton of $\mathrm{CO}_{2}$. It means that the cement production is responsible for $5 \%$ of global carbon dioxide emission. The direct source of carbon dioxide emission in the cement industry is the process of raw material calcination (approx. 62\%) and fuel combustion (approx. 38\%), while the indirect ones are means of transport and electricity production, as well as mining of mineral resources and primary fuels. High $\mathrm{CO}_{2}$ emission by the cement industry resulted in the development of a strategy to reduce this emission by: improving production processes, modernizing equipment, replacing primary fuels with alternative fuels from waste, optimizing the cement composition, and recovering heat energy from production processes. Striving for reduction of production costs and constraints on natural resources cause that use of waste materials as substitutes of traditional raw materials becomes increasingly important [1-3].

The dynamic development of sewage networks and municipal sewage treatment plants, visible in the last 20 years, leads to the formation of an increasing amount of municipal sewage sludge. Currently, the method of their management is subject to the Act of 14 December 2012 on waste (Journal of Laws 2013, item 21) [4] as well as executive 
regulations and laws specific to the way of their generating, processing and impact on the natural environment. Taking into account the ban on the storage of sewage sludge binding from 1 January 2016 [5], their management has become not only a technical and economic problem, but also an ecological one. Until then, the generated sewage sludge was landfilled or, after initial stabilization (aerobic, anaerobic, with lime), was released into the environment, e.g., as fertilizers or for earthworks. However, due to the sanitary hazard, high weight and hydration, they have always been a technical problem. Taking into account the presence of toxic substances and heavy metals, limiting the possibility of their use in agriculture, thermal methods are the most appropriate way of sewage sludge disposal. As a result of this process, the volume of waste (sludge) is reduced and the heat or electric energy is obtained, as well as the content of sulfur and nitrogen compounds in the exhaust gas is reduced. The secondary waste material generated in sewage sludge thermal treatment installations is waste (fly ash) with the code 190114 , which also requires appropriate management. Due to their origin, these ashes are characterized by specific properties (high phosphorus content), absent in by-products of coal combustion. In line with the idea of Circular Economy—a near-zero emission economy-ashes from sewage sludge should be treated as a potential product [4].

According to the binding regulations in Poland ([5], pos. 108), implementing the Directive of the European Parliament and Council (EU/2010/75) [6] within their scope, insofar as the ashes produced during the combustion of sewage sludge satisfy defined requirements, they can be used to prepare concrete mixtures for construction purposes, with the exception of buildings intended for the permanent residence of people or animals and for the production or storage of food. Due to the increase in the generated sewage sludge, it became necessary to find alternative methods of their application. One of such methods is utilization in technology of concrete and other building materials based on cement $[5,6]$.

Concrete is currently the most widely used man-made composite material, and second after water, in the entire range of materials used. It is an ecological material, made of local raw materials-aggregate, cement, water, admixtures and mineral additives, with the smallest carbon footprint. The use of secondary raw materials in the production of concrete-fly ash from thermal conversion of sewage sludge (as a partial replacement for cement-a cement substitute) is important not only from the economic but also the environmental point of view. In the environmental aspect, the benefits of using fly ash include, among others:

- limitation of the use of natural deposits, and thus savings in fossil fuels and natural resources and limitation of the devastation of the land surface as a result of the exploration of aggregates;

- reduction of the environmental pollution by reducing the emission of harmful gases (carbon dioxide);

- reduction of the amount of landfilled waste;

- recovery of land occupied by ash dumps.

The research on the fly ash from thermal conversion of sewage sludge (SSA) presented in the literature focuses on determining its potential for application in building materials such as: burnt tiles, bricks [7-9], glass ceramics [10-12], mortars, cement pastes and concretes [13-16]. This additive is used as a direct substitute for cement, sand or clay. It is assumed that mixing a certain amount of SSA with other ingredients does not adversely affect the compressive strength of mortars and concretes. Monzo et al. [17] found that mortars matured in water at $40{ }^{\circ} \mathrm{C}$ and containing up to $30 \%$ SSA did not show a reduction in compressive strength compared to reference mortars without the addition of ash. The changes in mortar strength are related to the pozzolanic properties of the SSA, the content of $\mathrm{C}_{3} \mathrm{~A}$ in the cement and the maturation conditions. In the studies of $\mathrm{Cyr}$ et al. [18], ash was introduced to the mortars in the amount of $25 \%$ and $50 \%$. It was estimated that SSA caused a decrease in compressive and bending strength compared to the control mortars. Lin et al. [19] concluded in their research that the fly ash from thermal conversion having a finer graining shows a higher pozzolanic activity, which results in a higher compressive 
strength of building materials. Chen et al. [20] analyzed the effect of ash as a substitute for cement and sand in concrete. Their tests showed satisfactory compressive strength of the prepared composites. Ing et al. [21] as well as Pinarli and Kaymal [22] confirmed that mortars containing up to $10 \%$ SSA have similar or greater compressive strength than conventional mortars. Baeza-Brotons et al. [23] proved a satisfactory strength after 28 days of maturation of concrete containing 5, 10, 15 and 20\% of ash. Moreover, they found that the ash influences the water absorption in the cement composite. In the studies of Chang et al. [24], it was confirmed that the fly ash used as an additive to concrete mix in the quantity up to $10 \%$ has a positive effect on compressive strength. In addition, this additive also affects the water absorption capacity of the material. Chen and Poon [25] proved in their studies that the pozzolanic effect of SSA is weaker than that of powdered fly ash (PFA). However, at the same exchange level of up to $20 \%$ of cement, the compressive and bending strength of the mortars are comparable. The optimal content of the fly ash from thermal conversion of sewage sludge in cement composites, according to the information provided by other authors, is within 5-20\% [26-34]. Pozzolanic properties and chemical composition of the fly ash from thermal conversion of sewage sludge used as a substitute of cement in concrete show analogy to traditional mineral additives [35].

The main goal of the research was to analyze the influence of the properties of the fly ash from sewage sludge on the strength parameters and frost resistance of concretes produced with their participation, in accordance with the assumptions of the circular economy. The obtained test results were compared to the zero sample containing no fly ash in its composition.

\section{Materials and Methods}

Procedures based on the guidelines contained in current EU regulations and standards were used to conduct the tests. Figure 1 shows a conceptual diagram of the conducted research.
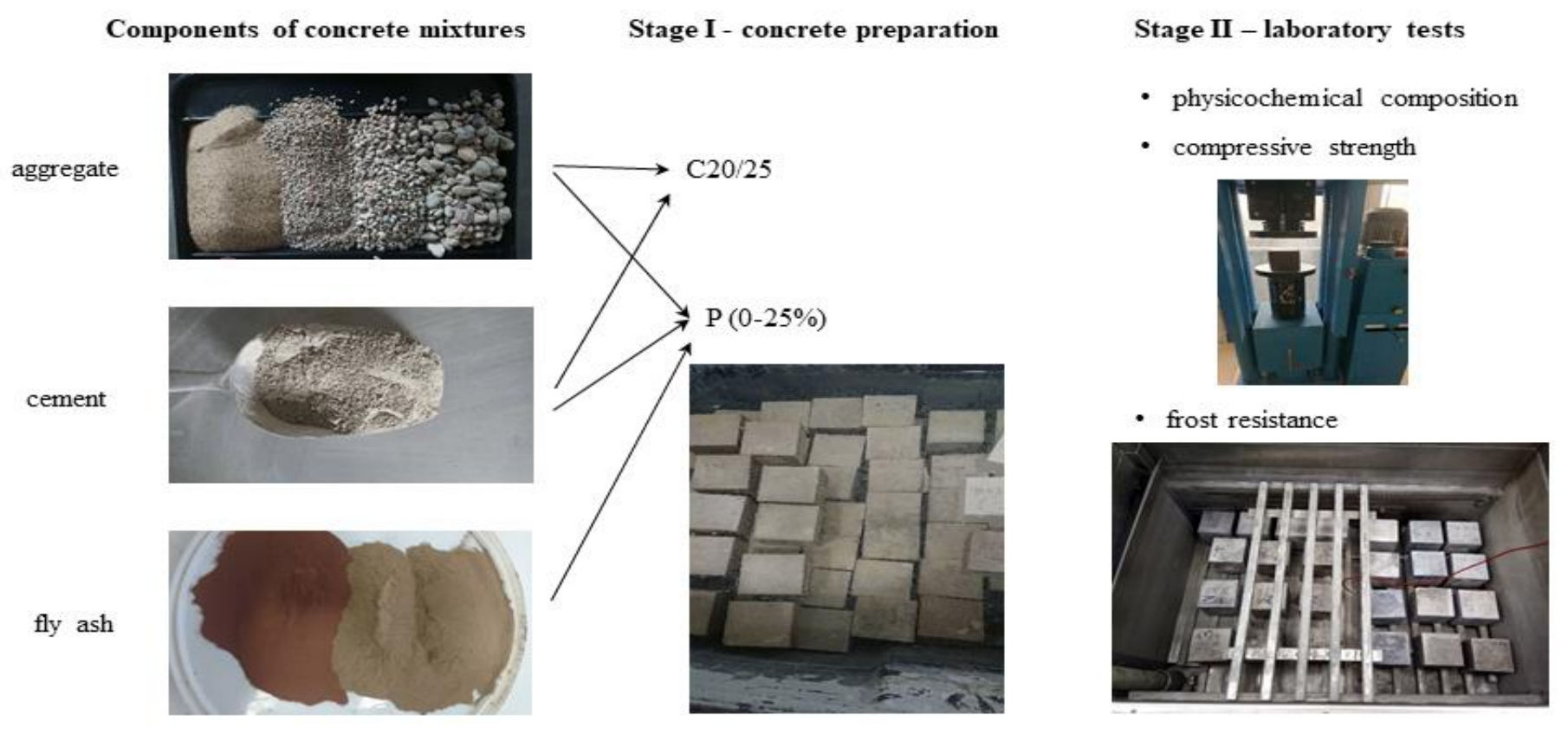

Figure 1. Conceptual diagram of the performed laboratory tests.

A mix of ordinary concrete of C20/25 class with the consistency of S3 was designed for experimental work, according to PN-EN 206+A1:2016-12, using the Bukowski's method of three equations [36,37]. For the preparation of the mixture, CEM I 42.5R Portland cement, pebble aggregate of fine fraction (grains of diameter 0-2 $\mathrm{mm}$ ) and coarse fraction (2-16 mm), water and an additive-fly ash-were used. In all compositions of the concrete mix, the same composition of the sand aggregate selected by the sieve analysis method and 
the constant composition of the gravel aggregate selected by the iteration method were maintained (Table 1). The phase composition and chemical and physical parameters of the cement according to the requirements of EN 197-1:2012 [38] are shown in Tables 2 and 3. As a partial replacement for cement, an additive was used-the fly ash from fluidized combustion of municipal sewage sludge in the "Czajka" sewage treatment plant in Warsaw. In order to compare the properties of ordinary concretes produced in a traditional way and concretes containing the fly ash from thermal conversion of sewage sludge in their composition, samples were prepared: OC—no additive, FA—with the addition of the fly ash from thermal conversion of sewage sludge in the amount of $5 \%$ to $25 \%$.

Table 1. Percentages of the aggregates selected by iterations.

\begin{tabular}{|c|c|c|c|c|c|}
\hline \multirow{2}{*}{ Fraction } & \multicolumn{3}{|c|}{$\begin{array}{l}\text { Fraction Mixing Percentage Ratio } \\
\text { (for Sand and Gravel) }\end{array}$} & \multicolumn{2}{|c|}{ Grain Composition [\%] } \\
\hline & I Stage & II Stage & III Stage & Sand & Gravel \\
\hline $0.0-0.125$ & & & \multirow{5}{*}{32} & 1.37 & 0.44 \\
\hline $0.0125-0.25$ & & & & 11.66 & 3.73 \\
\hline $0.25-0.50$ & & & & 37.24 & 11.92 \\
\hline $0.50-1.0$ & & & & 33.88 & 10.84 \\
\hline $1.0-2.0$ & & & & 15.85 & 5.07 \\
\hline $2.0-4.0$ & & 35 & \multirow{3}{*}{68} & & 23.80 \\
\hline $4.0-8.0$ & 47 & \multirow{2}{*}{65} & & & 20.77 \\
\hline $8.0-16.0$ & 53 & & & & 23.43 \\
\hline
\end{tabular}

Table 2. Phase composition and physical properties of cement CEM I 42.5 R.

\begin{tabular}{cccc}
\hline \multicolumn{4}{c}{ The Share of Mineral Phases CEM I [5 mass] } \\
\hline $\mathrm{C}_{3} \mathrm{~S}-61.9$ & $\mathrm{C}_{2} \mathrm{~S}-12.2$ & $\mathrm{C}_{3} \mathrm{~A}-7.6$ & $\mathrm{C}_{4} \mathrm{AF}-4.0$ \\
\hline $\begin{array}{c}\text { Blaine specific sur- } \\
\text { face area }\left[\mathrm{cm}^{2} / \mathrm{g}\right]\end{array}$ & $\begin{array}{c}\text { Beginning of bin- } \\
\text { ding time [min] }\end{array}$ & $\begin{array}{c}\text { Compressive strength } \\
\text { after 2 days [MPa] }\end{array}$ & $\begin{array}{c}\text { Compressive strength } \\
\text { after 28 days [MPa] }\end{array}$ \\
\hline 3331 & 217 & 21.0 & 49.7 \\
\hline
\end{tabular}

Table 3. Chemical properties of cement CEM I 42.5R.

\begin{tabular}{ccccc}
\hline Roasting Loss [\%] & $\begin{array}{c}\text { Sulfate Content } \\
\mathbf{S O}_{3}[\%]\end{array}$ & $\begin{array}{c}\text { Chloride Content } \\
\mathrm{Cl}^{-}[\%]\end{array}$ & $\begin{array}{c}\text { Alkali Content } \\
\mathbf{N a}_{2} \mathbf{O}_{\text {eq }}[\%]\end{array}$ & $\begin{array}{c}\text { Silica Content } \\
\mathrm{SiO}_{2}[\%]\end{array}$ \\
\hline 3.19 & 3.19 & 0.05 & 0.72 & 20.21 \\
\hline $\mathrm{Al}_{2} \mathrm{O}_{3}[\%]$ & $\mathrm{Fe}_{2} \mathrm{O}_{3}[\%]$ & $\mathrm{CaO}[\%]$ & $\mathrm{CaO}_{\mathrm{w}}[\%]$ & $\mathrm{MgO}[\%]$ \\
\hline 4.33 & 2.38 & 65.20 & 1.75 & 1.52 \\
\hline
\end{tabular}

The composition of the individual concrete mixes per $1 \mathrm{~m}^{3}$ is shown in Table 4 . 
Table 4. Concrete mix proportions by weight.

\begin{tabular}{|c|c|c|c|c|}
\hline \multirow{2}{*}{ Specification } & \multicolumn{4}{|c|}{ Mass of Concrete Ingredients $\left[\mathrm{kg} / \mathrm{m}^{3}\right]$} \\
\hline & Aggregate & Water & Cement & Fly Ash \\
\hline Concrete OC & 1789.57 & 191.78 & 412.01 & \\
\hline $\begin{array}{c}\text { FA } 5 \% \\
\text { Concrete with } 5 \% \text { of fly ash }\end{array}$ & 1789.57 & 191.78 & 391.41 & 20.60 \\
\hline $\begin{array}{c}\text { FA } 10 \% \\
\text { Concrete with } 10 \% \text { of fly ash }\end{array}$ & 1789.57 & 191.78 & 370.81 & 41.20 \\
\hline $\begin{array}{c}\text { FA } 15 \% \\
\text { Concrete with } 15 \% \text { of fly ash }\end{array}$ & 1789.57 & 191.78 & 350.21 & 61.80 \\
\hline $\begin{array}{c}\text { FA } 20 \% \\
\text { Concrete with } 20 \% \text { of fly ash }\end{array}$ & 1789.57 & 191.78 & 329.61 & 82.40 \\
\hline $\begin{array}{c}\text { FA } 25 \% \\
\text { Concrete with } 25 \% \text { of fly ash }\end{array}$ & 1789.57 & 191.78 & 309.01 & 103.00 \\
\hline
\end{tabular}

In order to determine the effect of the fly ash from thermal conversion of sewage sludge on the basic properties of concrete mix and concrete, the following properties were tested: bulk density (EN 12350-6:2011) [39], the consistency in a slump test (EN 123502:2011) [40] and air content in a pressure method (PN-EN 12350-7:2011) [41]. Compressive strength was tested in accordance with the guidelines specified in BS EN 12390-3: 201907 [42] in the hydraulic testing machine MATEST H011 (Brembate Sopra, Italy) after 28, 56 and 356 days of maturation. Frost resistance was tested with use of a direct method according to the procedure described in the PN-B-06265:2004 standard [43] in the "Toropol" chamber (Warsaw, Poland). The resistance of the modified concrete was carried out in a PK $1100 / 5$ furnace (Termolab SC, Warsaw, Poland) at a temperature of $400^{\circ} \mathrm{C}, 600^{\circ} \mathrm{C}, 800^{\circ} \mathrm{C}$. For testing, the samples were dried to a constant mass at a temperature of $105^{\circ} \mathrm{C} \pm 5{ }^{\circ} \mathrm{C}$ in a drying oven. The tests performed during the heating of the samples correspond to the conditions occurring during the fire [44]. Based on the results of these investigations and their statistical analysis, a material model was developed as a function describing the dependence between composition (component content) and properties of the composite. The input variables of the model are material factors determining the composition of concrete [45]. The output variables are the values of those characteristics of the material that determine its suitability. It is a statistical-experimental model determined as a quadratic function. On the basis of the determination coefficient $R^{2}$, an evaluation of the adaptation of the model to the results obtained was performed. The model was developed for the concretes with addition of ashes from thermal conversion of sewage sludge for which the compressive strength was examined after heating at $400^{\circ} \mathrm{C}, 600^{\circ} \mathrm{C}$ and $800^{\circ} \mathrm{C}$.

Municipal sewage supplied to the sewage treatment plant is mainly a mixture of domestic and industrial sewage, also supplied with rainwater and water infiltrating from the ground. The qualitative and quantitative characteristics of such wastewater depend on the type and condition of the sewage system, the amount of water used, the industrialization of the city or the standard of living of the inhabitants. Both the quantity and composition of wastewater flowing into sewage treatment plants generally change in the daily, weekly, monthly and yearly cycle. An important and binding rule for this reason is that there is no typical composition and quality of municipal wastewater, and thus there is no typical composition of fly ash generated during thermal conversion of sewage sludge. In order to identify the physical and chemical properties, tests were carried out on the fly ash from thermal conversion of sewage sludge as a material that is currently not widely used in the concrete technology, see Table 5. 
Table 5. Scheme of the methodology used in this study.

\begin{tabular}{|c|c|}
\hline Research & Test Method \\
\hline Particle size distribution & $\begin{array}{l}\text { The analysis was performed based on the phenomenon of laser } \\
\text { diffraction using the Mastersizer } 3000 \text { analyzer (Malvern } \\
\text { Instruments). The measurement was carried out in a dispersing } \\
\text { liquid (demineralized water) in the presence of an ultrasonic } \\
\text { probe in order to break up larger aggregates of the tested samples. } \\
\text { Grains with equivalent diameters ranging from } 0.1 \mu \mathrm{m} \text { to } \\
1000 \mu \mathrm{m} \text { were analyzed. }\end{array}$ \\
\hline $\begin{array}{l}\text { Morphology and chemical } \\
\text { composition in the } \\
\text { micro-area }\end{array}$ & $\begin{array}{l}\text { The determination was performed by the EDAX scanning electron } \\
\text { microscopy SEM Quanta } 250 \text { FEG FEI Company, with a system of } \\
\text { chemical composition analysis based on the X-ray radiation } \\
\text { energy dispersion-EDS (Energy Dispersive X-Ray Spectroscopy) }\end{array}$ \\
\hline $\begin{array}{l}\text { The chemical composition of } \\
\text { the material }\end{array}$ & $\begin{array}{l}\text { The composition was determined by the X-ray energy dispersion } \\
\text { fluorescence (XRF) method on an Epsilon } 3 \text { spectrometer } \\
\text { (Panalytical). The test was carried out in the measuring range of } \\
\text { the elements } \mathrm{Na}-\mathrm{Am} \text { using an apparatus equipped with the Rh } \\
\text { X-ray tube }(9 \mathrm{~W}, 50 \mathrm{kV}, 1 \mathrm{~mA}), 4096 \text {-channel spectrum analyzer, } \\
6 \text { measurement filters }(\mathrm{Cu}-500, \mathrm{Cu}-300, \mathrm{Ti}, \mathrm{Al}-50, \mathrm{Al}-200, \mathrm{Ag}) \text { and } \\
\text { a high-resolution semiconductor SDD detector ( } 50 \mu \mathrm{m} \text { thick } \\
\text { beryllium window) cooled with a Peltier cell. }\end{array}$ \\
\hline Mineral composition & $\begin{array}{l}\text { The composition was determined using X-ray phase analysis } \\
\text { (XRD). Measurements were made using the powder method } \\
\text { using a Panalytical X'pertPRO MPD X-ray diffractometer with a } \\
\text { PW } 3020 \text { goniometer. A copper tube (CuK } \alpha=1.54178 \AA \text { ) was } \\
\text { used as a source of the X-ray emission. X'Pert Highscore software } \\
\text { was used to process the diffraction data. Identification of mineral } \\
\text { phases was based on the PDF-2 release } 2010 \text { database formalized } \\
\text { by JCPDS-ICDD. }\end{array}$ \\
\hline Pozzolanic activity & $\begin{array}{l}\text { The determination was carried out in accordance with PN-EN } \\
\text { 450-1: } 2012 \text { and ASTM C379-65T }[46,47] \text {. }\end{array}$ \\
\hline
\end{tabular}

\section{Results and Their Discussion}

\subsection{Physical and Chemical Properties of Fly Ash}

The results of the analysis of the oxide composition of the fly ash from thermal conversion of sewage sludge are presented in Figure 2.

The loss on ignition of the fly ash in a fluidized bed furnace at a temperature exceeding $850^{\circ} \mathrm{C}$, expressing the content of unburned carbon in the sample, was low and amounted to $0.5 \%$. The largest share percentage in the ash accounted for silicon oxide $(23.77 \%)$ and calcium oxide $(18.64 \%)$. A high phosphate content of $23.08 \%$ was also noted. Additionally, the sum of the content of silicon dioxide $\left(\mathrm{SiO}_{2}\right)$, aluminum oxide $\left(\mathrm{Al}_{2} \mathrm{O}_{3}\right)$ and iron oxide $\left(\mathrm{Fe}_{2} \mathrm{O}_{3}\right)$ in the fly ash from sewage sludge was $60.23 \%$ and did not meet the requirements of PN-EN 450-1+A1:2012-65\% [46]; this standard, however, concerns silica fly ashes, generated in combustion and co-combustion of coal, not fly ashes from sewage sludge. It is assumed that the phosphate ions contained in the ash and the loss on ignition affect the compressive strength of concretes produced with the fly ash from the thermal conversion of sewage sludge $[48,49]$. It was observed that the fly ash from another batch used by the authors in previous studies $[16,29,30]$ was characterized by a poorer chemical composition than the fly ash used in the presented research. 


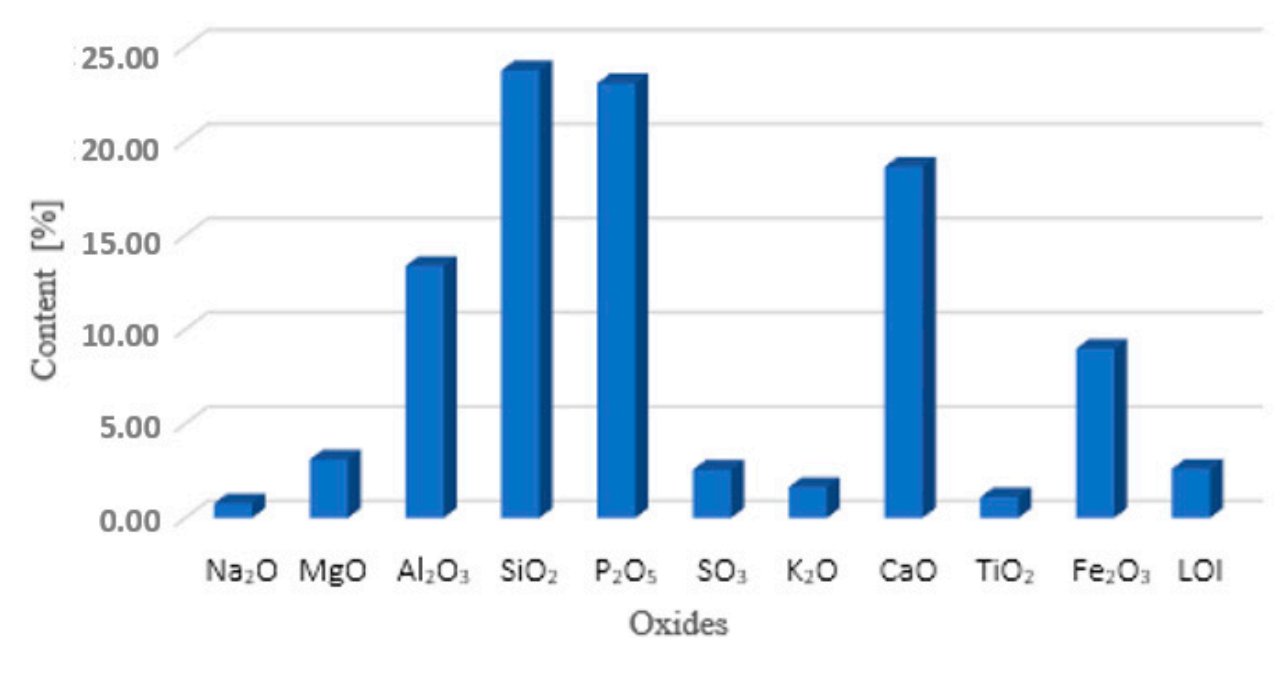

Figure 2. Oxide composition of the fly ash from thermal conversion of sewage sludge.

Volume distribution of individual grain fractions and SEM image are presented in Figure 3. The grains with a diameter of 2 to $250 \mu \mathrm{m}$ account for $94.39 \%$ of the volume. The density of ash determined according to PN EN 1097-07:2008 was $2534 \mathrm{~kg} / \mathrm{m}^{3}$ and the fineness tested according to PN EN 451-2:2017-06 amounted to 50.7\% [50,51]. The mineral composition of the fly ash from thermal conversion of sewage sludge is dominated by anhydrite and quartz; while taking into account the chemical analysis in the micro-area (SEM-EDS), grains with iron, phosphorus, aluminum and calcium in their content were dominant, along with grains containing potassium, magnesium and sodium, see Figure 4.
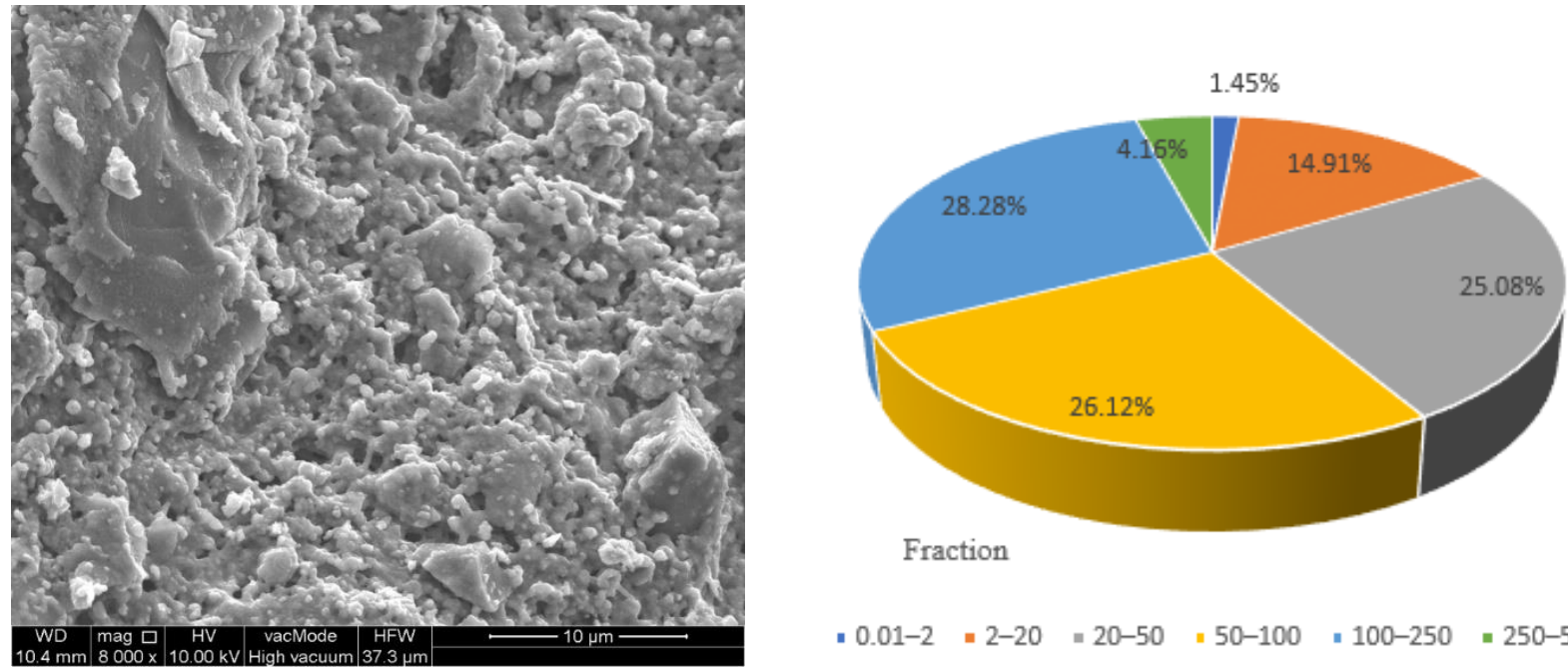

Fraction

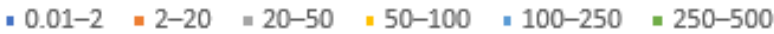

Figure 3. Volume distribution of grain fractions and SEM photo of the fly ash from thermal conversion of sewage sludge.

The pozzolanic activity of the fly ashes from thermal conversion of sewage sludge, determined as the total content of reactive $\mathrm{Al}_{2} \mathrm{O}_{3}$ and $\mathrm{SiO}_{2}$ based on ASTM C379-65T [47], was $20.31 \%$. The ash shows a pozzolanic character when the total content of oxides is over $20 \%$. In addition, the pozzolanic activity index, determined according to PN-EN 450-1:2012 after 28 days of maturation was $66.4 \%$, and after 90 days- $77.3 \%$. However, this standard applies to ashes from hard coal combustion-silica fly ash. The activity index after 28 days of maturation should reach the value $\geq 75 \%$, and after 90 days-the value $\geq 85 \%$ [46]. However, this standard applies to ashes from hard coal combustion—silica fly 
ash. According to the performed investigations, the pozzolanic activity of the fly ashes from thermal conversion of sewage sludge obtains the value $85 \%$ after a longer period- 120 days. The results prove that the fly ashes from thermal conversion of sewage sludge used as the substitute of the defined quantity of cement, can be used in the concrete manufacturing. The concretes containing such fly ashes obtain the designed compressive strength after 28 days of curing and it increases in next days of curing.

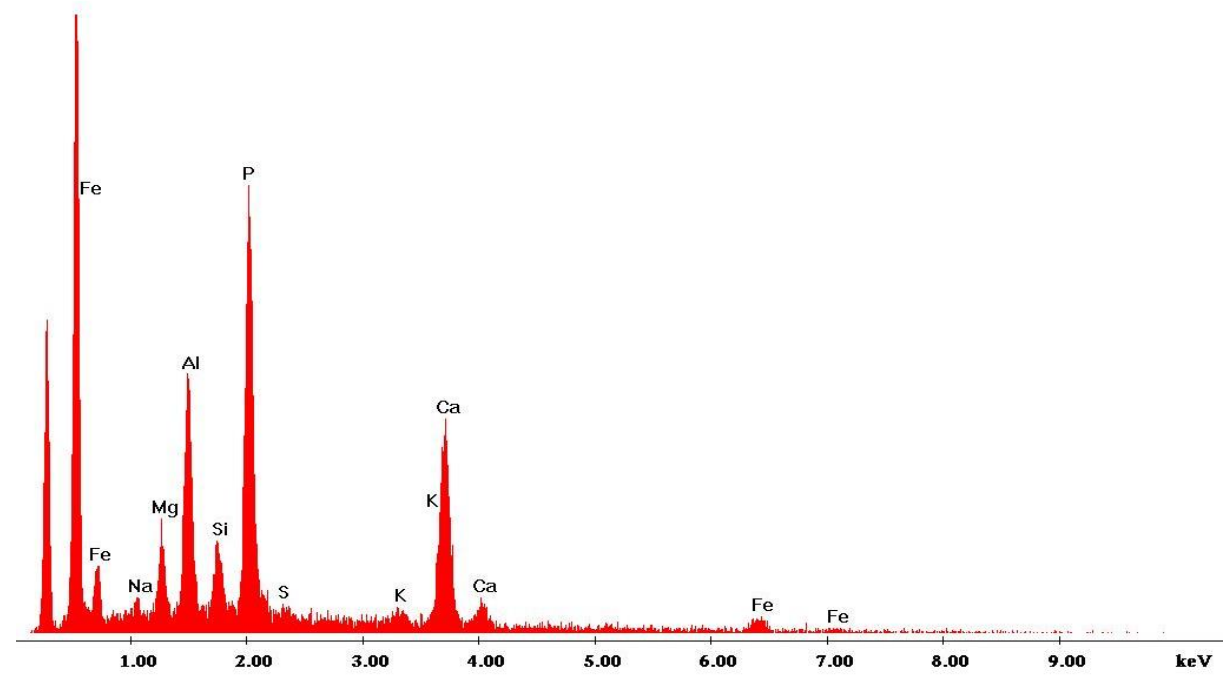

Figure 4. Mineral composition of the fly ash from thermal conversion of sewage sludge.

\subsection{Properties of the Concrete Mix}

Based on the test results carried out on the fresh concrete mix, it was found that the fly ash from thermal conversion of sewage sludge affects its individual parameters. The lowest air content was observed for the sample of the reference concrete mixture OC, equal to $1.8 \%$, while the highest- $2.9 \%$-in the mixture in which $25 \%$ of the cement was replaced by the ash (FA 25\%). The density of the concrete mix ranged from 2.322 to $2.394 \mathrm{~kg} / \mathrm{m}^{3}$. The concrete mix without the additive obtained a plastic consistency, similarly to the concrete mixes containing different contents of the additive-Figure 5 . It is quite confusing that the density of the concrete mixes with the additive is higher than that of the reference concrete, despite the higher air content of the mixes with the additive. This result is confirmed in another publication [52] describing investigations conducted by the authors and concerning application of the fly ashes from thermal conversion of sewage sludge. However, this phenomenon requires further investigations in an aim to explain its nature and reasons.

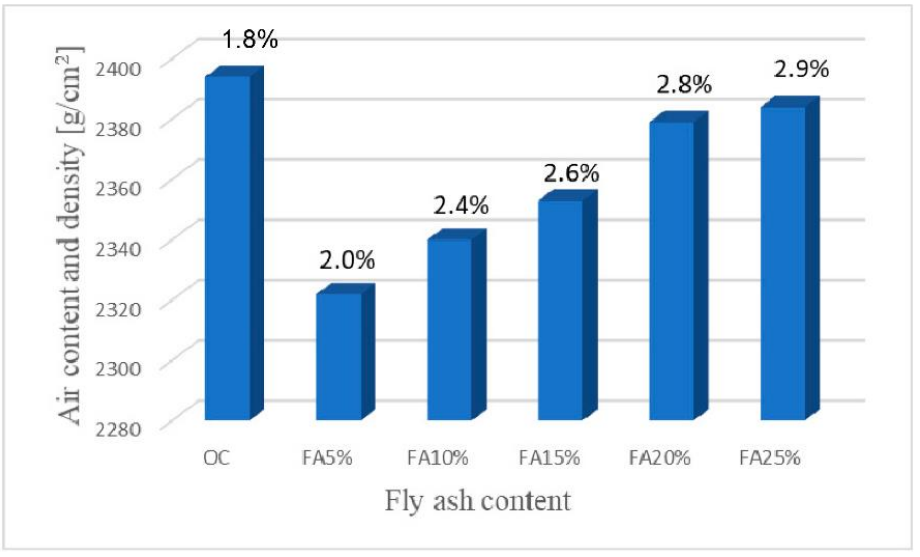

Figure 5. Density (bars) and air content (percentages) of the concrete mixes. 


\subsection{Compressive Strength}

The results of measurements of the average compressive strength of concrete samples with a different content of the fly ash from thermal conversion of sewage sludge are shown in Figure 6.

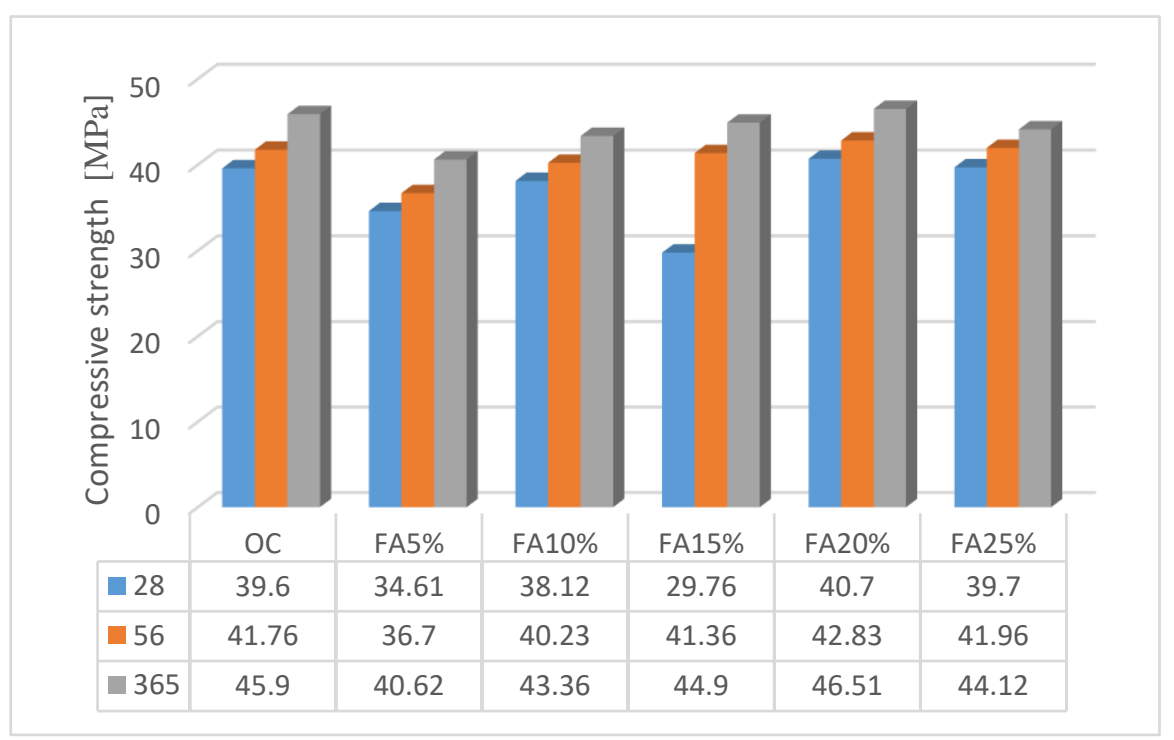

Figure 6. Average compressive strength in different periods of concrete maturation.

Replacement of the cement by the ash from thermal conversion of sewage sludge influenced the compressive strength in comparison to the reference concrete. The highest compressive strength after 28 days of maturation, equal to $40.70 \mathrm{MPa}$, was achieved by concrete samples in which $20 \%$ cement was replaced by the fly ash, while the lowest strength was $29.76 \mathrm{MPa}$-for samples where $15 \%$ of cement was replaced with ash. Compared to the reference concrete, the increase in strength for the concrete FA20\% was $2.8 \%$, while the decrease in the concrete FA5\% was $24.8 \%$. The highest compressive strength after 56 days, equal to $42.83 \mathrm{MPa}$, was achieved by the concrete FA20\%, while the lowest one, equal to $36.70 \mathrm{MPa}$, by the concrete FA5\%. After a one-year maturation period, it was observed that the lowest compressive strength equal to $40.62 \mathrm{MPa}$ was again obtained by the concrete FA5\%, the highest one, equal to $46.51 \mathrm{MPa}$ - by the concrete FA20\%. The fly ash from thermal conversion of sewage sludge used as a substitute for cement in quantities of up to $20 \%$ results in an increase in strength if compared to the reference concrete without the addition, see Figure 6 . The investigations conducted by the authors $[29,30,52,53]$ and concerning the impact of the fly ash from thermal conversion of sewage sludge on strength compression in different maturation periods confirms the positive effect of this type of ash $[29,30,52,53]$. When assessing the chemical composition of the used ash [30], it was observed that for the ash obtained from the "Czajka" sewage treatment plant in Warsaw, the values of compressive strength were lower than for the concrete with the ash from the sewage treatment plant in Cracow. The increase in strength is influenced by a higher concentration of the oxides $\mathrm{SiO}_{2}, \mathrm{Al}_{2} \mathrm{O}_{3}, \mathrm{Fe}_{2} \mathrm{O}_{3}$ in total and a lower concentration of $\mathrm{P}_{2} \mathrm{O}_{5}$, $\mathrm{CaO}, \mathrm{SiO}_{2}$ and $\mathrm{Al}_{2} \mathrm{O}_{3}$ in total. Similarly to the research results presented by other authors $[26-28,54]$, the cost-effective replacement of the binder with the fly ash is within the range of $5 \%$ to $20 \%$. In addition, the physicochemical and pozzolanic properties of ashes from sewage sludge indicate the possibility of using this additive as a substitute in concrete technology [26,27].

\subsection{Frost Resistance}

Table 6 shows the obtained results of the compressive strength of the samples after 150 freezing cycles and of the comparative samples. If cyclically frozen and thawed, 
the concrete can be subjected to internal or surface damages. The surface damage leads to continual pitting of the surface, hence to decrease in mass of the tested samples [55]. According to PN-88/B-06250, the concrete samples subjected to freezing and thawing cycles should not show any damage or cracks, and their weight loss cannot exceed $5 \%$. Additionally, the decrease in compressive strength should not exceed 20\% [16]. An important factor affecting the frost resistance of the concrete is the air content. Air bubbles in the concrete can provide empty spaces for accommodating the ice expansion, thus relieving the hydrostatic pressure and osmotic pressure during the low temperature cycle. On the other hand, the ice expansion could cause severe cracking stress inside the concrete $[55,56]$.

Table 6. Summary of the average strength decrease of the samples subjected to freezing and the average weight loss of the samples.

\begin{tabular}{|c|c|c|c|c|c|c|c|}
\hline \multirow{3}{*}{$\mathbf{N}^{\mathbf{o}}$} & \multirow{3}{*}{ Sample } & \multicolumn{2}{|c|}{$\begin{array}{c}\text { Average Compressive } \\
\text { Strength }\end{array}$} & \multirow{2}{*}{$\begin{array}{c}\text { Average } \\
\text { Strength } \\
\text { Decrease } \\
\text { of Frozen } \\
\text { Samples }\end{array}$} & \multicolumn{2}{|c|}{ Average Mass } & \multirow{2}{*}{$\begin{array}{c}\text { Average } \\
\text { Loss in } \\
\text { Mass }\end{array}$} \\
\hline & & $\begin{array}{l}\text { before } \\
\text { Freezing }\end{array}$ & $\begin{array}{c}\text { after } 150 \\
\text { Freeze-Thaw } \\
\text { Cycles }\end{array}$ & & $\begin{array}{l}\text { before } \\
\text { Freezing }\end{array}$ & $\begin{array}{c}\text { after } 150 \\
\text { Freeze-Thaw } \\
\text { Cycles }\end{array}$ & \\
\hline & & [MPa] & [MPa] & {$[\%]$} & {$[g]$} & [g] & {$[\%]$} \\
\hline 1 & OC & 43.12 & 41.87 & -2.899 & 2366 & 2362 & 0.169 \\
\hline 2 & FA5\% & 37.87 & 35.99 & -4.964 & 2416 & 2409 & 0.289 \\
\hline 3 & FA10\% & 42.65 & 41.78 & -2.039 & 2361 & 2342 & 0.804 \\
\hline 4 & FA $15 \%$ & 43.90 & 43.12 & -1.777 & 2329 & 2331 & 0.086 \\
\hline 5 & FA20\% & 42.34 & 39.98 & -5.574 & 2378 & 2372 & 0.252 \\
\hline 6 & FA25\% & 41.33 & 38.76 & -6.218 & 2363 & 2357 & 0.254 \\
\hline
\end{tabular}

On the basis of the conducted tests, it was found that the reference concrete samples and samples containing different contents of the fly ash from the thermal conversion of sewage sludge showed no damage or cracks upon macroscopic evaluation. Their weight loss did not exceed 5\% and the decrease in compressive strength-20\% (what satisfied the requirements of the standard [43]). Samples subjected to 150 cycles of freezing and thawing in which the cement was replaced with ash in amount of up to $25 \%$ can be classified as having the degree of frost resistance F150. Among the comparative samples, the lowest compressive strength, equal to $37.87 \mathrm{MPa}$, was achieved by the FA5\% samples, and the highest one, equal to $43.90 \mathrm{MPa}$, by the FA15\% samples. When assessing the compressive strength of the samples after the freeze-thaw cycles, the lowest compressive strength of $35.99 \mathrm{MPa}$ was achieved by the FA5\% samples-similar to the comparative samples, while the highest strength of $41.87 \mathrm{MPa}$ - by the reference concrete sample (OC). In addition, it was observed that the smallest decrease in compressive strength was obtained for samples in which the cement was replaced with the fly ash in the amount of $15 \%$. The mean weight loss of individual samples after freezing was insignificant and ranged from 0.086 (FA15\%) to 0.804 (FA10\%).

It was confirmed in the tests that the addition of the fly ashes from thermal conversion of sewage sludge positively affects the frost resistance of concretes produced with such additive. According to the results presented in previous investigations by the authors, maximally $5-20 \%$ of the cement can be replaced by the fly ash $[31,55]$. Taking into account the chemical composition of the used ashes [55], it was noted that the higher compressive strength is obtained by the concrete containing the fly ash from Cracow than that from Warsaw. Lower concentration of $\mathrm{P}_{2} \mathrm{O}_{5}, \mathrm{CaO}, \mathrm{SiO}_{2}$ and $\mathrm{Al}_{2} \mathrm{O}_{3}$ in total, as well as higher concentration of $\mathrm{SiO}_{2}, \mathrm{Fe}_{2} \mathrm{O}_{3}$ and $\mathrm{Al}_{2} \mathrm{O}_{3}$ in total, increases the compressive strength of the produced concretes.

\subsection{Material Model after Heating of Samples}

The objective of the testing of concretes in high temperatures was to check out how the concrete containing the fly ashes from thermal conversion of sewage sludge behaves in high temperatures $\left(300,500,700{ }^{\circ} \mathrm{C}\right)$. In this way, it was being checked whether such concrete 
can be used, e.g., for construction of tunnels, and whether in case of fire, the construction is safe. After heating of the reference concrete samples and the samples with different fly ash content from thermal conversion of sewage sludge, cracks and scratches were observed on their surface. The average compressive strength, after heating at the temperature of $300{ }^{\circ} \mathrm{C}$, increased for the CO concrete by $9.1 \mathrm{MPa}$ and for the concrete samples FA5\% by 3.0 $\mathrm{MPa}$, if compared to the compressive strength of the samples stored at $20^{\circ} \mathrm{C}$. For the concretes FA10\%, FA15\% and FA $20 \%$, the compressive strength decreased by $3.5 \mathrm{MPa}$, 8.0 $\mathrm{MPa}$ and $10.3 \mathrm{MPa}$, respectively. Increase of the heating temperature to $500{ }^{\circ} \mathrm{C}$ caused a decrease in strength by approx. 10\% (FA5\%), 23\% (FA10\%), 37\% (FA15\%) and 30\% (FA20\%). The concretes at $700{ }^{\circ} \mathrm{C}$ presented a fall in the range of $30 \%$ (OC) to $60 \%$ (FA15\%), if compared to the reference concrete samples. On the basis of the test, it was observed that a smaller amount of the fly ash in the concrete has a positive effect on the compressive strength of the samples exposed to fire.

Figure 7 and Table 7 present regression graphs for temperatures and individual values of compressive strength, along with a correlation equation. The obtained graphs present a negative correlation. There is a dependence between the values where the fall (growth) in the compressive strength is accompanied by the growth (fall) in the temperature.

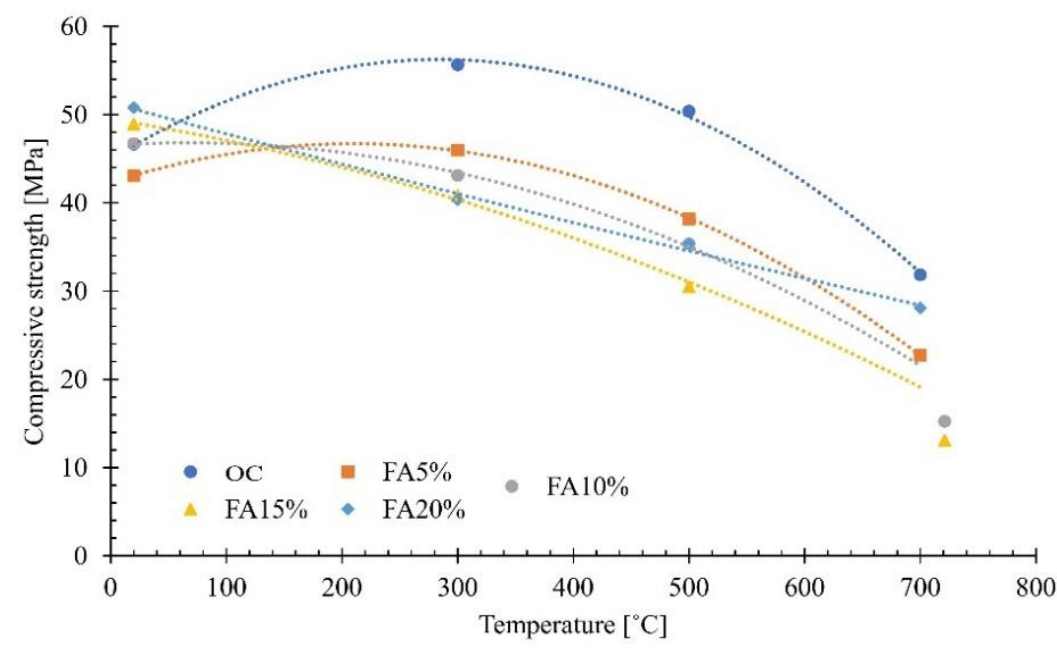

Figure 7. Correlation graph for the concrete samples.

Table 7. Material model (second degree polynomials) of concrete with the addition of FA with one variable.

\begin{tabular}{ccc}
\hline Predicted Parameter & $\begin{array}{c}\text { Model Equation } \\
\mathbf{x} \text {-Temperature }\left[{ }^{\circ} \mathrm{C}\right]\end{array}$ & $\begin{array}{c}\text { Coefficient of } \\
\text { Determination } \mathbf{R}^{2}\end{array}$ \\
\hline Compressive strength of OC $[\mathrm{MPa}]$ & $\mathrm{f}_{\mathrm{cm}}=-0.0001 \mathrm{x}^{2}+0.0793 \mathrm{x}+44.98$ & 0.9974 \\
Compressive strength of FA5\% $[\mathrm{MPa}]$ & $\mathrm{f}_{\mathrm{cm}}=-0.0001 \mathrm{x}^{2}+0.0419 \mathrm{x}+42.303$ & 0.9999 \\
Compressive strength of FA10\% $[\mathrm{MPa}]$ & $\mathrm{f}_{\mathrm{cm}}=-2.5775 \mathrm{x}^{2}+4.518 \mathrm{x}+44.693$ & 0.9995 \\
Compressive strength of FA15\% $[\mathrm{MPa}]$ & $\mathrm{f}_{\mathrm{cm}}=-0.765 \mathrm{x}^{2}-6.097 \mathrm{x}+55.86$ & 0.9998 \\
Compressive strength of FA20\% $[\mathrm{MPa}]$ & $\mathrm{f}_{\mathrm{cm}}=0.8 \mathrm{x}^{2}-11.304 \mathrm{x}+60.91$ & 0.9886 \\
\hline
\end{tabular}

\section{Conclusions}

From the ecological point of view, the reuse of waste-fly ash with the code 1901 14-brings great economic benefits. Proper disposal and thermal treatment allows for its reuse. The obtained research results proved that it is possible to use the fly ash from thermal conversion of sewage sludge for the production of concrete as a partial substitute for cement. The obtained results and their analysis allow for the following conclusions:

1. The generated waste-the fly ash from thermal conversion of sewage sludge used for the production of concrete positively affects its compressive strength and frost resistance. 
2. The concrete containing the fly ash from incineration of sewage sludge in its composition presented a compressive strength comparable to that of the reference concrete without additives. The ash can be used as a cement substitute if its content does not exceed $20 \%$. The average compressive strength of concrete containing $20 \%$ of the fly ash from thermal conversion of sewage sludge after 28,56 and 365 days of maturation was equal to $40.7 \mathrm{MPa}, 42.8 \mathrm{MPa}$ and $46.5 \mathrm{MPa}$, respectively.

3. There is no typical composition and quality of municipal wastewater, and thus there is no typical composition of fly ash generated during thermal conversion of sewage sludge.

4. The fly ash from thermal conversion of sewage sludge has a different physicochemical composition compared to the silica fly ash used in concrete technology and does not meet the requirements of PN-EN 450-1: 2012. The oxides of silicon, calcium, phosphorus and aluminum had the largest share in the composition of the ash samples.

5. Concretes made with ash in the amount of $5 \%-25 \%$ are frost-resistant. The concrete containing ash from sewage sludge obtained satisfactory strength parameters after 150 freezing and thawing cycles.

6. The action of high temperature damaged the structure of the tested concrete, and visible scratches and cracks appeared on its surface. After heating of the concrete samples at the temperature of $300{ }^{\circ} \mathrm{C}$, an increase in compressive strength for the OC concrete by $9.1 \mathrm{MPa}$ was recorded, and for the concrete samples FA5\%-by $3.0 \mathrm{MPa}$. The temperature increase to $500{ }^{\circ} \mathrm{C}$ caused a decrease in strength in the range of $10 \%$ (FA5\%)-37\% (FA15\%) in all cement composites. The concrete at the temperature of $700{ }^{\circ} \mathrm{C}$ presented a decrease in the range of $30 \%(\mathrm{OC})$ to $60 \%$ (FA15\%) in relation to the samples made of the reference concrete.

Author Contributions: Conceptualization, G.R.; methodology, G.R.; validation, G.R.; formal analysis, G.R.; investigation, G.R.; resources, G.R. and M.C.; writing-original draft preparation, G.R. and, M.C.; writing-review and editing, M.C. and M.Ż.; visualization, G.R. All authors have read and agreed to the published version of the manuscript.

Funding: This research received no external funding.

Institutional Review Board Statement: Not applicable.

Informed Consent Statement: Not applicable.

Data Availability Statement: Data is not publicly available, though the data may be made available on request from the corresponding author.

Conflicts of Interest: The authors declare no conflict of interest.

\section{References}

1. Rocznik Statystyki Międzynarodowej (International Statistics Yearbook). Available online: https://stat.gov.pl/en/topics/statisticalyearbooks/statistical-yearbooks / concise-statistical-yearbook-of-poland-2020,1,21.html (accessed on 12 February 2021).

2. IEA-Shaping a Secure and Sustainable Energy Future for All. Available online: www.iea.org (accessed on 12 February 2021).

3. Deja, J.; Antosiak, B. Degree of progress of the fly ash reaction in alkali-activated fly-ash binders. Cem. Lime Concr. 2012, 17, 67-76.

4. Ustawa z Dnia 14 Grudnia 2012 r. o Odpadach (Dz.U. 2013, poz. 21). Available online: https://isap.sejm.gov.pl/isap.nsf/ DocDetails.xsp?id=WDU2013000002 (accessed on 25 April 2019).

5. Rozporządzenie Ministra Rozwoju z Dnia 21 Stycznia 2016 r. W Sprawie Wymagań Dotyczących Prowadzenia Procesu Termicznego Przekształcania Odpadów Oraz Sposobów Postępowania z Odpadami Powstałymi w Wyniku Tego Procesu. (Dz.U. 2016 poz. 108). Available online: http:/ /isap.sejm.gov.pl/isap.nsf/DocDetails.xsp?id=WDU20160000108 (accessed on 24 April 2019).

6. Directive 2010/75/UE of the European Parliament and the Council of 24 November 2010 on Industrial Emissions (Integrated Pollution Prevention and Control). Available online: https: / / eur-lex.europa.eu/LexUriServ/LexUriServ.do?uri=OJ\%3AL\%3A2 010\%3A334\%3A0017\%3A0119\%3Aen\%3APDF (accessed on 24 April 2019).

7. Lin, D.F.; Luo, H.L.; Cheng, J.F.; Zhuang, M.L. Strengthening tiles manufactured with sewage sludge ash replacement by adding micro-carbon powder. Mater. Struct. 2016, 49, 3559-3567. [CrossRef]

8. Lin, D.F.; Luo, H.L.; Lin, K.L.; Liu, Z.K. Effects of waste glass and waste foundry sand additions on reclaimed tiles containing sewage sludge ash. Environ. Technol. 2017, 38, 1-10. [CrossRef] 
9. Lynn, C.J.; Dhir, R.K.; Ghataora, G.S. Sewage sludge ash characteristics and potential for use in bricks, tiles and glass ceramics. Water Sci. Technol. 2016, 74, 17-29. [CrossRef] [PubMed]

10. Suzuki, S.; Tanaka, M.; Kaneko, T. Glass-ceramic from sewage sludge ash. J. Mater. Sci. 1997, 32, 1775-1779. [CrossRef]

11. Park, Y.J.; Moon, S.O.; Heo, J. Crystalline phase control of glass ceramics obtained from sewage sludge fly ash. Ceram. Int. 2003, 29, 223-227. [CrossRef]

12. Merino, I.; Arévalo, L.F.; Romero, F. Preparation and characterization of ceramic products by thermal treatment of sewage sludge ashes mixed with different additives. Waste Manag. 2007, 27, 1829-1844. [CrossRef] [PubMed]

13. Piasta, W.; Lukawska, M. The effect of sewage sludge ash on properties of cement composites. Proc. Eng. 2016, 161, 1018-1024. [CrossRef]

14. Vouk, D.; Nakic, D.; Stirmer, N.; Cheeseman, C.R. Use of sewage sludge ash in cementitious materials. Rev. Adv. Mater. Sci. 2017, $49,158-170$.

15. Chakraborty, S.; Jo, B.W.; Jo, J.H.; Baloch, Z. Effectiveness of sewage sludge ash combined with waste pozzolanic minerals in developing sustainable construction material: An alternative approach for waste management. J. Clean. Prod. 2017, 153, 253-263. [CrossRef]

16. Rutkowska, G.; Fronczyk, J.; Filipchuk, S. Influence of fly-ash properties from thermal transformation of sewage sludge on ordinary concrete parameters. Acta Sci. Pol. Archit. 2020, 19, 43-54. (In Polish) [CrossRef]

17. Monzó, J.; Paya, J.; Borrachero, M.V.; Peris-Mora, E. Mechanical behavior of mortars containing sewage sludge ash (SSA) and Portland cements with different tricalcium aluminate content. Cem. Concr. Res. 1999, 29, 87-94. [CrossRef]

18. Cyr, M.; Coutand, M.; Clastres, P. Technological and environmental behavior of sewage sludge ash (SSA) in cement-based materials. Cem. Concr. Res. 2007, 37, 1278-1289. [CrossRef]

19. Lin, K.L.; Chang, W.C.; Lin, D.F.; Luo, H.L.; Tsai, M.C. Effects of nano-SiO 2 and different ash particle sizes on sludge ash-cement mortar. J. Environ. Manag. 2008, 88, 708-714. [CrossRef] [PubMed]

20. Chen, M.; Blanc, D.; Gautier, M.; Mehu, J.; Gourdon, R. Environmental and technical assessments of the potential utilization of sewage sludge ashes (SSAs) as secondary raw materials in construction. Waste Manag. 2013, 33, 1268-1275. [CrossRef] [PubMed]

21. Ing, D.S.; Chin, S.C.; Guan, T.K.; Suil, A. The use of sewage sludge ash (SSA) as partial replacement of cement in concrete. ARPN J. Eng. Appl. Sci. 2016, 11, 3771-3775.

22. Pinarli, V.; Kaymal, G. An innovative sludge disposal option-reuse of sludge ash by incorporation in construction materials. Environ. Technol. 1994, 15, 843-852. [CrossRef]

23. Baeza-Broton, F.; Garces, P.; Paya, J.; Saval, J.M. Portland cement systems with addition of sewage sludge ash. Application in concretes for the manufacture of blocks. J. Clean. Prod. 2014, 82, 112-124. [CrossRef]

24. Chang, F.; Lin, J.; Tsai, C.; Wang, K. Study on cement mortar and concrete made with sewage sludge ash. Water Sci. Technol. 2010, 62, 1689-1693. [CrossRef]

25. Chen, Z.; Poon, C.S. Comparative studies on the effects of sewage sludge ash and fly ash on cement hydration and properties of cement mortars. Constr. Build. Mater. 2017, 154, 791-803. [CrossRef]

26. Lin, K.-L.; Lin, C.-Y. Hydration characteristics of waste sludge ash utilized as raw cement material. Cem. Concr. Res. 2005, 35, 1999-2007. [CrossRef]

27. Yen, C.L.; Tseng, D.H.; Lin, T.T. Characterization of eco-cement paste produced from waste sludges. Chemosphere 2011, 84, 220-226. [CrossRef]

28. Ferreira, C.; Ribeiro, A.; Ottosen, L. Possible applications for municipal solid waste fly ash. J. Hazard. Mater. 2003, 96, 201-216. [CrossRef]

29. Rutkowska, G.; Wichowski, P.; Fronczyk, J.; Franus, M.; Chalecki, M. Use of fly ashes from municipal sewage sludge combustion in production of ash concretes. Constr. Build. Mater. 2018, 188, 874-883. [CrossRef]

30. Rutkowska, G.; Wichowski, P.; Franus, M.; Mendryk, M.; Fronczyk, J. Modification of ordinary concrete using fly ash from combustion of municipal sewage sludge. Materials 2020, 13, 487. [CrossRef] [PubMed]

31. Chen, Z.; Li, J.S.; Poon, C.S. Combined use of sewage sludge ash and recycled glass cullet for the production of concrete blocks. J. Clean. Prod. 2018, 171, 1447-1459. [CrossRef]

32. Lynn, C.J.; Dhir, R.K.; Ghataora, G.S.; West, R.P. Sewage sludge ash characteristics and potential for use in concrete. Constr. Build. Mater. 2015, 98, 767-779. [CrossRef]

33. Wang, A.; Zhang, C.; Sun, W. Fly ash effects: I. The morphological effect of fly ash. Cem. Concr. Res. 2003, 33, 2023-2029. [CrossRef]

34. Yadav, S.; Agnihotri, S.; Gupta, S.; Tripathi, R. Incorporation of STP sludge and fly ash in brick manufacturing: An attempt to save the environment. Int. J. Adv. Res. Technol. 2014, 3, 138-144. [CrossRef]

35. Yusur, R.O.; Noor, Z.Z.; Din, M.F.M.; Abba, A.H. Use of sewage sludge ash (SSA) in the production of cement and concrete-A review. Int. J. Glob. Environ. Issues 2012, 12, 214-228. [CrossRef]

36. Bundyra-Oracz, G. Różnice między PN-88/B-06250 Beton zwykły i PN-EN 206-1: 2003 PN-EN 206+A1:2016-12 Beton. Część 1: Wymagania, właściwości, produkcja i zgodność. Pr. Inst. Tech. Bud. 2008, 37, 3-26.

37. Jamroży, Z. Beton i Jego Technologie; Wydawnictwo Naukowe PWN: Warsaw, Poland, 2015.

38. PN-EN 197-1:2012. Cement. Part 1: Composition, Requirements and Compliance Criteria for Common Cements; Polish Standardization Committee: Warsaw, Poland, 2012. 
39. PN-EN 12350-6:2011. Testing of Fresh Concrete. Part 6: Density; Polish Standardization Committee: Warsaw, Poland, 2011.

40. PN-EN 12350-2:2011. Testing of Fresh Concrete. Part 2. Slump Test; Polish Standardization Committee: Warsaw, Poland, 2011.

41. PN-EN 12350-7:2011. Testing of Fresh Concrete. Part 7: Air Content-Pressure Method; Polish Standardization Committee: Warsaw, Poland, 2011.

42. PN-EN 12390-3:2019-07. Testing of Hardened Concrete. Part 3: Compressive Strength of Test Specimens; Polish Standardization Committee: Warsaw, Poland, 2019.

43. PN-B-06265:2004. Plain Concrete; Polish Standardization Committee: Warsaw, Poland, 2004.

44. PN-EN 1363-2:2001. Fire Resistance Tests. Part 2: Alternative and Additional Procedures; Polish Standardization Committee: Warsaw, Poland, 2001.

45. Czarnecki, L.; Łukowski, P. Model materiałowy betonów żywicznych. In Proceedings of the Scientific Technical Conference (Materiały Konferencji Naukowo-Technicznej) MATBUD’96, Kraków, Poland, 19-22 June 1996.

46. British Standards Institution (BSI). Fly Ash for Concrete. Part 1: Definition, Specifications and Conformity Criteria; British Standards Institution: London, UK, 2012.

47. ASTM C379-65T. Specification for Fly Ash for Use as a Pozzolanic Material with Lime; Polish Standardization Committee: Warsaw, Poland, 1996.

48. Williams, P.T. Waste Treatment and Disposal, 2nd ed.; John Wiley \& Sons: Chichester, UK, 2005.

49. Tkaczewska, E. Właściwości cementów zawierających różne frakcje ziarnowe krzemionkowych popiołów lotnych. Drogi Mosty 2008, 4, 47-80.

50. PN-EN 1097-7:2008. Determination of the Filler Density; Polish Standardization Committee: Warsaw, Poland, 2008.

51. PN-EN 451-2:2017-06. Fly Ash Test Method-Determination of Fineness by Wet Sieving; Polish Standardization Committee: Warsaw, Poland, 2017.

52. Rutkowska, G.; Ogrodnik, P.; Fronczyk, J.; Bilgin, A. Temperature influence on ordinary concrete modified with fly ash from thermally conversed municipal sewage sludge strength parameters. Materials 2020, 13, 5259. [CrossRef]

53. Rutkowska, G. Fly ash from the thermal transformation of sewage as an additive to concrete. Acta Sci. Pol. Archit. 2020, 19, 93-104. (In Polish) [CrossRef]

54. Małolepszy, J.; Tkaczewska, E. Influence of fly ashes from the co-combustion of coal and biomass on the hydration process and properties of cement. Concr. Days 2006, 23, 591-601. (In Polish)

55. Wang, L.; He, T.S.; Zhou, Y.X. The influence of fiber type and length on the cracking resistance, durability and pore structure of face slab concrete. Constr. Build. Mater. 2021, 282, 122706. [CrossRef]

56. Chen, Y.; Cen, G.P.; Cui, Y.H. Comparative study on the effect of synthetic fiber on the preparation and durability of airport pavement concrete. Constr. Build. Mater. 2018, 184, 34-44. [CrossRef] 